\title{
BERPIKIR DAN BERPERILAKU DENGAN RASA
}

\author{
Devi Kurniawati Homan \\ Jurusan Desain Komunikasi Visual, School of Design, BINUS University \\ Jln. K.H. Syahdan No. 9, Palmerah, Jakarta Barat 11480 \\ devikurniawatihoman@yahoo.com
}

\begin{abstract}
Article discusses the importance for a designer to understand about psychology and consumers' behaviors that act based on their feelings. Human as a complicated living creature has lot of feelings before making a reaction. The reaction itself is based on their own feeling from their experiences or the others' before. In our daily life, we think a lot based on our feelings. We associate a stimulus with an unconscious physical or emotional response. A designer often needs to make a promotion, branding, and campaign for a product or something else. So, it is important for designers to know their targets and behaviors. By understanding their target behaviors, it is easier to predict or to design the reaction and response when the product or campaign is launched. The understanding of the psychology study is important for a designer as well as understanding the other branch of study beside their own study about aesthetics. When the designer understands a lot of things, they can make a creative, good and useful visual communication.
\end{abstract}

Keywords: thoughts, behavior

\begin{abstract}
ABSTRAK
Artikel membahas pentingnya pemahaman seorang desainer mengenai psikologi dan pola pikir target sasarannya yang biasa berpikir dan berperilaku berdasarkan rasa. Manusia sebagai makhluk yang rumit memiliki banyak pertimbangan berdasarkan pengalaman sendiri maupun pengalaman orang di sekelilingnya. Dalam keseharian, tanpa sadar kita banyak berpikir dan berperilaku menggunakan rasa. Kita mengasosiasikan sebuah rangsangan dalam kondisi fisik tidak sadar yang menghasilkan respons emosi terhadap suatu kondisi. Sebagai seorang desainer yang sering kali dihadapkan pada suatu permasalahan dalam membuat suatu promosi atau pun kampanye pencitraan, tentunya penting untuk memahami sisi psikologi target sasarannya. Dengan memahami pola pikir pemirsa, maka akan lebih mudah untuk memprediksi atau bahkan merancang reaksi maupun respons yang diharapkan ketika promosi ataupun kampanye pencitraan suatu produk maupun jasa yang diluncurkan. Pemahaman tentang ilmu psikologi ini penting bagi desainer, sama seperti pentingnya pemahaman banyak cabang ilmu lain di samping keilmuan estetik. Dengan memahami banyak cabang ilmu, seorang desainer diharapkan dapat membuat suatu komunikasi visual yang kreatif, solutif, dan tepat guna.
\end{abstract}

Kata kunci: berpikir, berperi laku 


\section{PENDAHULUAN}

Dalam keseharian, tanpa sadar kita sering melakukan penilaian berdasarkan rasa. Seperti misalnya ketika kita melihat sebuah poster suatu promosi yang sangat ramai dan penuh. Tanpa sadar kita menilai, "rasanya informasinya ga jelas ya" atau "rasanya pusing deh bacanya". Atau mungkin ketika melewati deretan kemasan makanan di sebuah supermarket, dan kita tertarik pada sebuah kemasan hanya karena desainnya yang menarik, "rasanya jadi pingin beli deh". Bahkan secara tidak sadar pun kadang kita membali sesuatu karena sebelumnya kita telah terpengaruh oleh sebuah iklan suatu produk maupun jasa tertentu, yang pada alam bawah sadar kita, terasosiasikan dengan sesuatu, dan akhirnya kita membeli atau menggunakan produk/jasa tersebut. Padahal secara kebutuhan, kita sama sekali tidak membutuhkan produk maupun jasa tersebut. Hal ini erat sekali kaitannya dengan budaya hidup konsumtif masyarakat dengan pola pencitraan suatu produk maupun jasa yang diciptakan oleh seorang desainer.

Banyak sekali penilaian dan perilaku kita yang dilakukan berdasarkan rasa. Seperti teori Classical Condition (Lidwell, Holden, Butler, 2003), sebuah teknik yang digunakan untuk mengasosiasikan sebuah rangsangan dengan kondisi fisik tidak sadar ataupun respons emosi terhadap kondisi tersebut. Teknik ini pada mulanya dipelajari oleh ahli jiwa yang mempelajari perilaku. Teori ini ditemukan ketika pekerja lab menyadari bahwa anjing yang biasa mereka beri makan selalu berliur ketika memasuki ruangan. Itu karena kebiasaan mereka memberi makan anjing tersebut diasosiasikan oleh sang anjing dengan makanan. Sama seperti pada manusia, teknik ini banyak digunakan dalam iklan maupun kampanye suatu produk maupun jasa dalam berbagai media. Sebagai contoh, tentunya Anda masih mengingat iklan sebuah pasta gigi yang baru-baru ini mengampanyekan gosok gigi sebelum tidur pada anak-anak. Iklan ini diasosiasikan pada kebersihan dan kesehatan gigi anak. Namun secara tidak sadar, iklan ini akan mengubah perilaku hampir semua anak Indonesia yang berpuluh tahun kemudian menjadi dewasa dan tetap mempraktikkan konsumsi pasta gigi tersebut. Sama seperti yang terjadi di Jepang berpuluh tahun silam, di mana sebuah merek kopi mengampanyekan konsumsi kopi pada masyarakat jepang yang memiliki budaya minum teh, dan sama sekali tidak memiliki budaya minum kopi. Mereka memberikan permen kopi pada anak-anak Jepang, yang akhirnya terbiasa dengan rasa kopi, yang kini setelah dewasa menjadikan kopi sebagai salah satu budaya baru mereka. Rasa pada manusia mengasosiasikan sesuatu secara tidak sadar pada sesuatu hal lainnya. Hal ini penting untuk dicermati oleh desainer sebagai seorang perancang kampanye dan pencitraan bagi sebuah produk maupun jasa. Dengan mengerti teknik ini, seorang desainer dapat merancang suatu kampanye pencitraan secara efektif dan terpadu. Dengan mengerti teknik ini pula seorang desainer dapat mengubah kebiasaan masyarakat, bahkan membuat sebuah budaya baru di masyarakat.

\section{METODE PENELITIAN}

Penelitian bagaimana seseorang berpikir dan berperilaku berdasarkan rasa ini dilakukan berdasarkan studi lapangan dan studi literatur. Pertama-tama, penulis melakukan pendekatan studi kaji dengan melihat pengalaman-pengalaman dan pengamatan pribadi penulis di lapangan dan lingkungan kerja. Selain itu, penulis melakukan studi literatur dengan mencari berbagai sumber yang terkait dengan berpikir dengan rasa melalui media cetak maupun media elektronik. Sumber informasi diseleksi, dievaluasi, dan dijadikan pendukung dalam penulisan ini.

\section{HASIL DAN PEMBAHASAN}

Rasa adalah fungsi fisiologi, seperti penglihatan, pendengaran, peraba, penciuman, dan pengecap. Indra tersebutlah yang memberikan masukan untuk memahami makna atau mengerti persepsi/hakikat dari sesuatu. Rasa memberikan daya gerak yang memengaruhi buah pikiran, karya, 
dan perilaku seseorang. Saat seniman memberikan rasa pada karyanya, baik itu karya gerak, lukis ataupun produk, ada emosi yang dapat dirasakan oleh pemirsanya. Rasa itu sendiri dapat dinyatakan dalam berbagai macam cara yang berbeda tergantung masing-masing individu. Setiap rasa berbeda, dalam arti rasa yang sama bisa disampaikan berbeda, sesuai dengan cara berpikir masing-masing pribadi.

Pada filsafat estetika India kuno dijelaskan sembilan rasa sebagai indikasi dari emosi utama manusia. Berasal dari kata 'Navarasa', di mana 'Nava' berarti sembilan dan 'Rasa' berarti esensi/emosi. Sembilan rasa ini merupakan tulang punggung estetika India, sejak dituliskan dalam 'Natyasastra' (200-300SM). Yang mendalam pada filsafat ini adalah dampak yang dihasilkannya, yang disebut sebagai 'Veda kelima', di mana tujuan/motivasi utama dari pelaku seni adalah membangkitkan rasa bagi pemirsanya melalui karya seni mereka, baik itu berupa seni tari, seni lukis, dll. Sembilan rasa tersebut adalah cinta, kasih sayang/simpati, kekaguman, perdamaian, kegembiraan, kepahlawanan, ketakutan, kejijikan/kebencian, dan kemarahan.

\section{Ś ngāram/Shingara (cinta)}

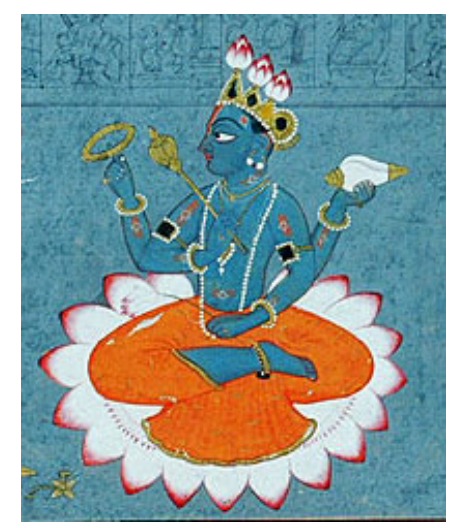

Gambar 1 Wisnu

Dewa pelindungnya adalah Wisnu. Warnanya hijau muda. Cinta erotis yang merupakan sumber penciptaan, energi yang melahirkan dunia dan memegang kekuatan besar dalam dirinya sendiri.

\section{Kāru yam/Karuna (kasih sayang/simpati)}

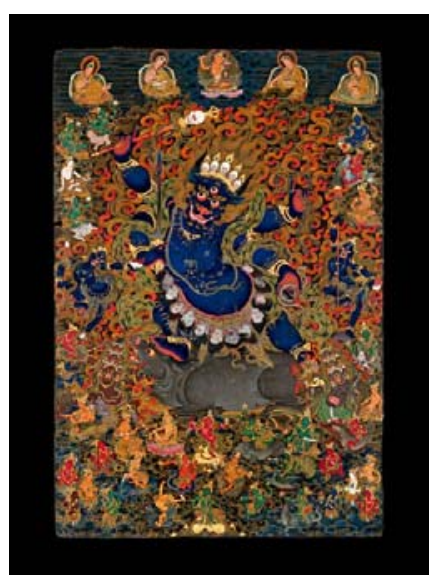

Gambar 2 Yama 
Dewa pelindungnya adalah Yama. Warnanya abu-abu. Emosi yang digambarkan sebagai debaran jantung, empati, saat melihat penderitaan orang lain. Rasa yang membuat kita lembut, menerima, tidak menghakimi, membantu kita memahami orang lain, dan membuat persahabatan sejati.

\section{Adbhutam/Adbhuta (kekaguman)}

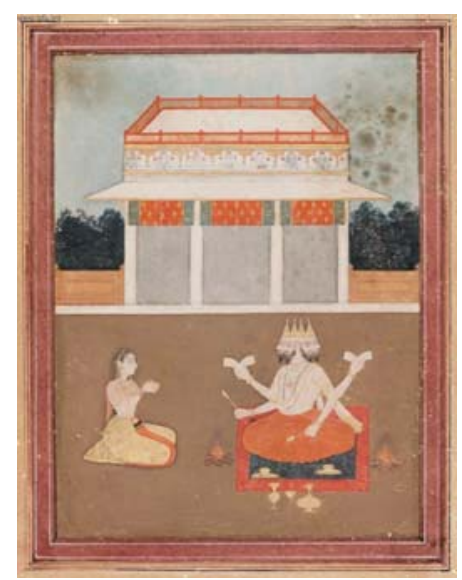

Gambar 3 Brahma

Dewa pelindungnya adalah Brahma. Warnanya kuning. Kekaguman pada semua hal yang terjadi di sekeliling kita, bahkan kagum pada hal yang buruk yang menimpa kita. Rasa kagum akan membuat pikiran kita segar dan dipenuhi oleh gairah hidup. Layaknya seperti anak kecil yang memiliki rasa kagum akan segala sesuatu, dan rasa antusias saat mengalami segala sesuatu untuk pertama kalinya.

\section{Śāntam/Shant (perdamaian)}

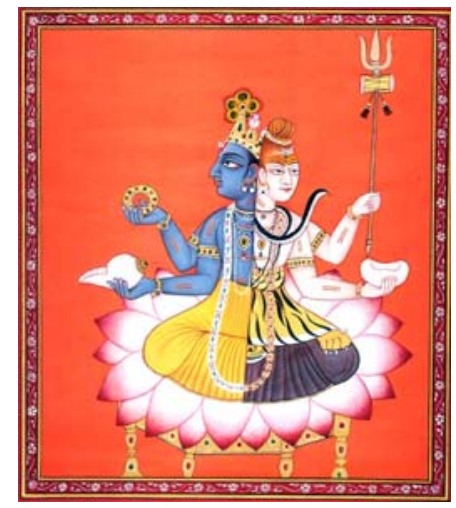

Gambar 4 Wisnu

Dewa pelindungnya adalah Wisnu. Warnanya biru. Filosofi Rasa yang ditambahkan kemudian (antara abad 6-10). Energi yang tenang dan damai, yang tidak membutuhkan aktivitas maupun emosi. Baik kekerasan maupun perdamaian, semua berawal dari pikiran. Seperti Mahatma Gandhi yang digambarkan dalam hidupnya, orang bukan hanya harus lepas dari tindakan kekerasan namun harus lepas pula dari pikiran dan ucapannya tentang kekerasan.

\section{Hāsyam/Hasya (kegembiraan)}

Dewa pelindungnya adalah Pramata. Warnanya putih. Melihat segala sesuatu dengan rasa humor akan mencerahkan saat-saat gelap dalam kehidupan yang tidak sempurna. Saat kita bisa melihat 
humor dalam situasi yang sulit, kita merasakan suatu yang mengangkat beban tersebut. Pada saat ketegangan itu berakhir, saat itu pula kita bisa melanjutkan hidup.

\section{Vīram/Veer (kepahlawanan)}

Dewa pelindungnya adalah Indra. Warnanya kekuning-kuningan. Kepahlawanan dalam dunia modern bukan hanya dilihat dari kekuatan fisik, seperti yang biasa kita asosiasikan dengan kata kepahlawanan. Namun kepahlawanan di sini lebih kepada rasa percaya diri, kekuatan dalam diri saat menghadapi tekanan ataupun kelemahan pribadi. Menghadapi masalah dan tantangan, menyelesaikannya dengan berani tanpa melarikan diri.

\section{Bhayānakam/Bhaya (ketakutan)}

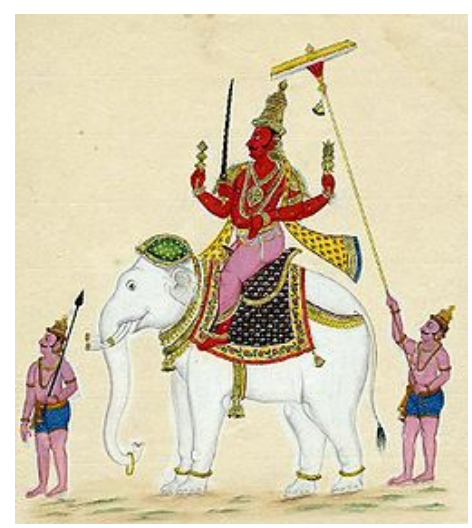

Gambar 5 Kala

Dewa pelindungnya adalah Kala. Warnanya hitam. Dari semua emosi negatif, rasa takut bisa menjadi rasa yang paling melemahkan. Rasa takut memenjarakan diri kita sendiri ke bagian terkecil dari diri kita. Saat diliputi rasa takut, maka energi seseorang akan diwarnai oleh ketidakberdayaan, merasa kehilangan, kesepian, ditinggalkan dan dilupakan. Rasa takut itu sendiri tidak ada dengan sendirinya. Rasa takut muncul dari alam bawah sadar, sebuah kondisi primal yang dibangkitkan ketika ada sesuatu dalam pandangan seseorang yang akan merugikan atau mengancam jiwanya. Benih rasa takut muncul dengan sendirinya sebagai bentuk pertahanan diri seseorang. Seiring dengan perkembangan kehidupan, maka rasa takut seseorang akan tumbuh menjadi lebih besar, dan semakin bervariasi.

\section{Bībhatsam/Vibhatsa (kejijikan/kebencian)}

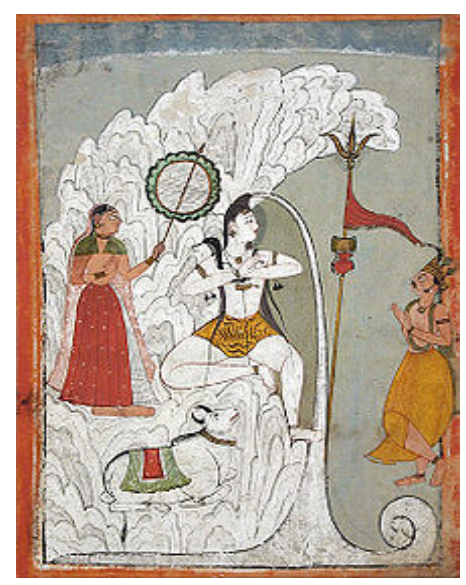

Gambar 6 Shiwa 
Dewa pelindungnya adalah Shiwa. Warnanya biru. Rasa atau pikiran untuk menghakimi sesuatu ataupun seseorang. Pikiran seseorang tidak pernah berhenti, bahkan sering kali realitas menjadi tidak nyata ketika dimanipulasi oleh pikiran yang ingin melihat, hanya sesuatu yang diinginkannya.

\section{Raudram/Raudra (kemarahan)}

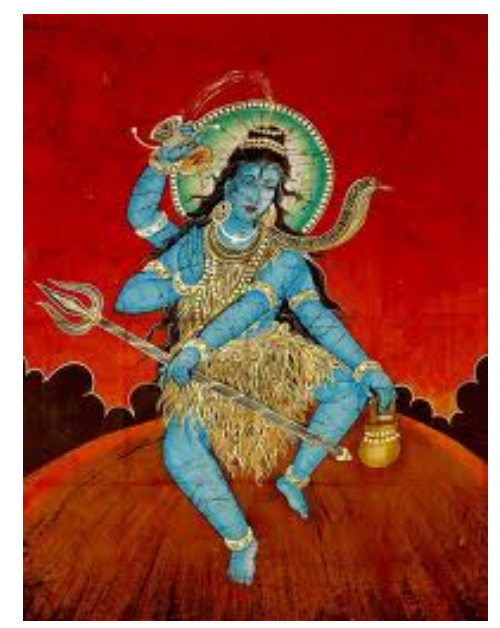

Gambar 7 Rudra

Dewa pelindungnya adalah Rudra. Warnanya merah. Emosi dasar yang ada pada diri semua orang. Bahkan ketika seseorang tidak memiliki masalah dengan tabiat pemarah, akan ada saatnya ketika dia merasa marah pada sesuatu. Kemarahan itu sendiri merupakan emosi yang destruktif. Ketika kemarahan tidak bisa diredam, maka akan berujung pada kekerasan.

Sebagai contoh ekstrem mengenai berpikir dengan rasa, kita dapat lihat pada tokoh Helen Keller. Dari sosok Helen Keller yang kehilangan indra penglihatan dan pendengarannya akibat penyakit keras yang diderita ketika usia dini, kita bisa mengetahui bahwa berpikir tidak hanya berpusat di otak. Berkat bantuan dari gurunya, Anne Sullivan, bagi Helen Keller merasa, membau, dan meraba sama dengan membaca dan berpikir.

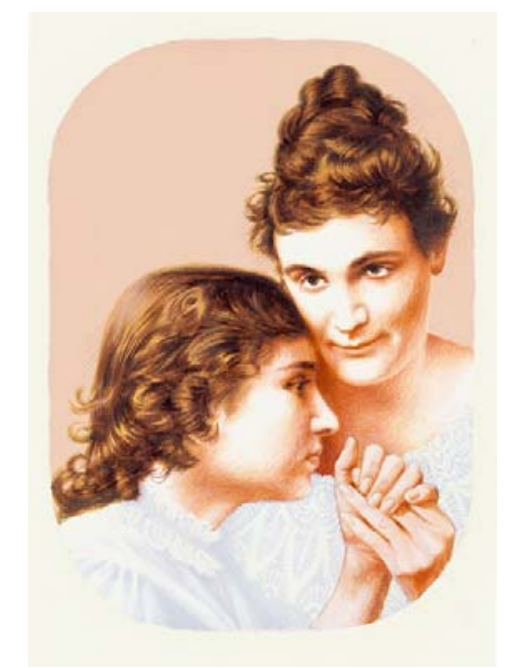

Gambar 8 Hellen Keller dan Anne Sullivan 
Dalam dunia seni dan desain, sebenarnya banyak seniman dan desainer yang menyampaikan rasa atau esensi dari sesuatu pada hasil karyanya dengan penggambaran yang dianggap paling mewakili imajinasi atau gambaran mental sang seniman atau desainer itu. Dia berharap ada kesan rasa atau esensi khusus yang ditangkap pemirsa melalui karyanya tersebut. Salah satu cara yang digunakan dalam menampilkan sesuatu dengan kuat/khusus adalah dengan cara menyangatkan atau melebihlebihkan satu atau beberapa aspek yang mau ditampilkan. Efek melebih-lebihkan tersebut biasa disebut dengan peak shift effect (efek perubahan yang tajam). Pada iklan majalah maupun televisi bahkan media lainnya, tanpa sadar kita sering menjumpai suatu iklan ataupun kampanye yang dikondisikan untuk diasosiasikan dengan rasa tertentu. Gambar, penggunaan peran yang menarik akan merangsang otak dan tanpa sadar akan diasosiasikan dengan respons positif terhadap produk ataupun jasa yang ditawarkan. Sebaliknya, penggunaan visual yang mengganggu seperti kekerasan, ekstremitas, kecelakaan, sakit, akan merangsang otak untuk merespons negatif terhadap produk ataupun jasa yang ditawarkan. Pada sebuah percobaan klasik, seorang anak kecil dihadapkan pada seekor tikus putih dan suara yang sangat bising. Anak ini tumbuh dengan ketakutan bukan hanya pada tikus putih (di mana dia tidak takut sebelumnya), tetapi juga pada berbagai benda berbulu lainnya, seperti misalnya, mantel bulu. Banyak sekali fobia yang ditimbulkan sehubungan dengan asosiasi manusia terhadap rasa. Seperti banyak anak takut ke dokter gigi karena rasa sakit yang dirasakan pada kunjungan sebelumnya. Maka, saat ini banyak dokter gigi memberikan hadiah pada anak kecil untuk mengubah asosiasi rasa tersebut.

Penggunaan classical conditioning maupun peak shift effect dapat memengaruhi tampilan sebuah desain maupun memengaruhi perilaku masyarakat. Sebagai contoh, pada iklan produk kecantikan wajah bagi wanita dewasa, penggambaran wajah karakter wanita tersebut akan dibuat sehalus dan secantik mungkin. Lain halnya dengan produk perawatan pria dewasa, karakter tokoh pria tersebut akan ditampilkan macho, dengan pori-pori besar namun bersih dan terawat. Pada kedua iklan tadi tentunya akan ditampilkan pemeran yang menarik yang dianggap sesuai dan mewakili karakter produk. Semua ini akan membantu pemirsa dalam mengasosiasikan produk yag ditawarkan dengan rasa positif yang terbentuk dari pengalaman pribadi maupun pengalaman umum di masyarakat. Lihat gambar 9 dan 10.

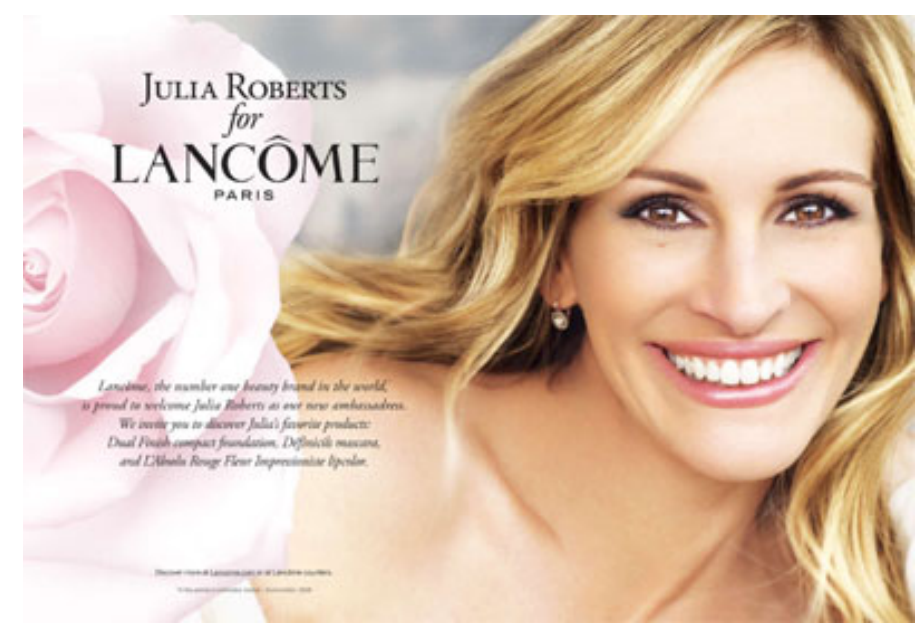

Gambar 9 Contoh Iklan Produk Kecantikan Wajah bagi Wanita Dewasa 


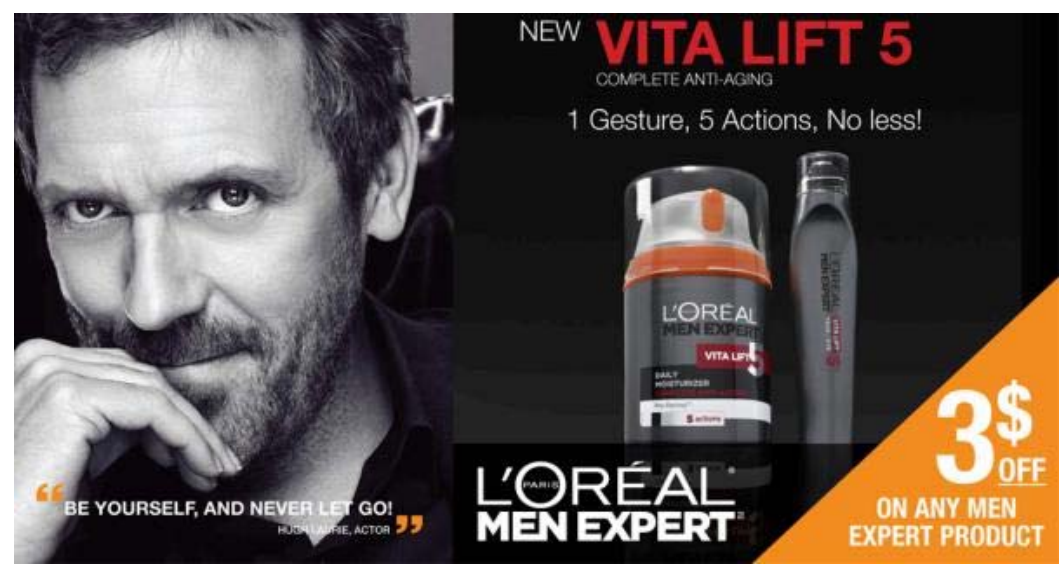

Gambar 10 Contoh Iklan Produk Perawatan Wajah bagi Pria Dewasa

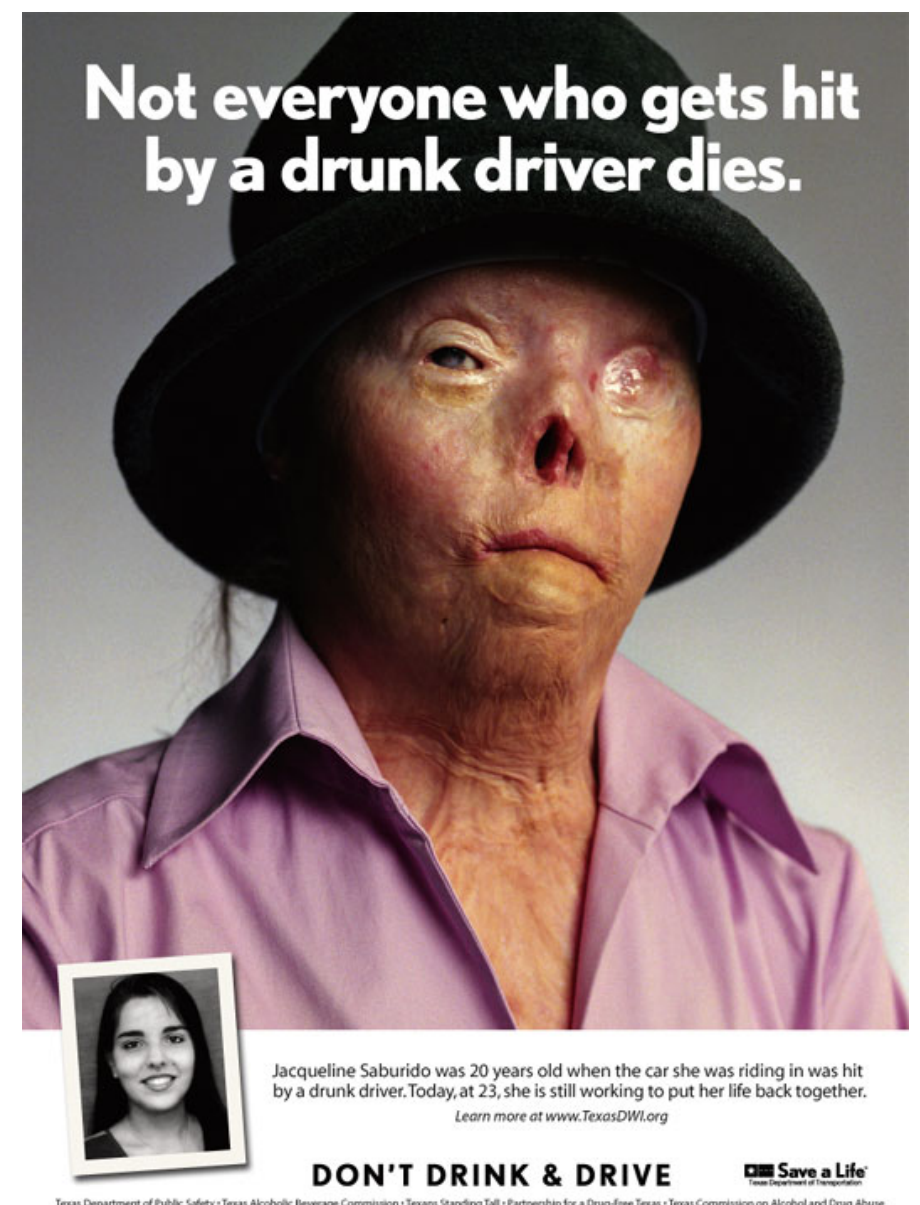

Gambar 11 Contoh Kampanye “Don’t Drink \& Drive”

Tentunya masih lekat dalam ingatan kita berita duka pada akhir Januari 2012 lalu mengenai tragedi Tugu Tani yang diakibatkan oleh pengemudi yang mabuk. Dengan ramainya berita dan informasi di berbagai media yang memberitakan betapa parahnya dampak yang terjadi, kita merasa sedih dan marah pada perilaku buruk yang tidak bisa ditoleransi tersebut. Ada contoh kasus yang mirip dialami oleh Jacqueline Saburido, yang akhirnya menjadi kampanye antimabuk dan mengemudi. Pada contoh gambar 11 dapat dilihat bahwa asosiasi rasa negatif pun dapat digunakan untuk hal yang 
positif. Pada kampanye ini dapat dilihat betapa parahnya luka yang diderita Jacqueline karena perilaku buruk mengemudi dan mabuk. Hal ini membangkitkan reaksi emosi yang didasarkan pada rasa bahwa mengemudi dan mabuk adalah sesuatu yang tidak bisa ditoleransi. Kesuksesan dan kekuatan pada kampanye ini bisa berhasil karena keberanian Jacqueline Saburido yang memperkenankan untuk membagi kisah hidupnya setelah kecelakaan yang diakibatkan oleh pengemudi yang mabuk menjadi sebuah kampanye antimabuk dan mengemudi.

Dengan berkembangnya teknologi, bukan hanya indra penglihat saja yang bisa dipengaruhi, hampir semua sistem pengindraan kita dapat merasakan dan dipengaruhi oleh sebuah promosi ataupun kampanye yang terintegrasi. Kini, asosiasi terhadap rasa dapat dibuat dari penggunaan suara ataupun bebauan. Seperti misalnya, ketika ingin menampilkan efek horor, tentu suara/musik akan berbeda dengan suara/musik efek romantis. Sama halnya dengan bebauan, apabila kita membeli produk keluaran apple, bau yang dihasilkan ketika kita membuka segel kemasan produk baru tersebut, akan sama di setiap produk keluaran apple lainnya. Lain halnya bebauan yang keluar dari produk baru keluaran merek lain. Dengan merasakan dan ikut terlibat atau berinteraksi dalam sebuah kampanye atau pencitraan, target sasaran akan menjadi lebih mudah terpengaruhi. Pengalamannya dalam interaksi tersebut akan menjadi acuan rasa dalam menentukan reaksi maupun respons selanjutnya.

\section{SIMPULAN}

Dari pembahasan tadi dapat disimpulkan bahwa dengan rasa, manusia dapat berpikir dan menilai sesuatu. Dengan mengerti pola pikir manusia, seorang desainer dapat membuat dan menghasilkan karya yang dapat diarahkan pada reaksi emosi yang diharapkan dari pemirsanya. Ilmu mendesain bagi seorang desainer ternyata belum cukup hanya berupa pemahaman warna, layout, maupun estetika semata, namun juga bagaimana psikologi dan pola pikir manusia. Seorang desainer diharapkan menghasilkan karya yang tepat guna dan solutif. Oleh karena itu, seorang desainer diharapkan untuk memahami berbagai macam ilmu lain di luar desain dan estetikanya. Selain pemahaman terhadap psikologi dan pola pikir target sasaran, banyak cabang ilmu lain yang perlu dipelajari. Pada kajian berikutnya akan dibahas bagaimana cabang ilmu lainnya berpengaruh terhadap ilmu desain.

\section{DAFTAR PUSTAKA}

Lidwell, W., Holden, K., \& Jill. (2003). Universal Principles of Design. Massachusetts: Rockport.

Marianto, M. D. (2011). Menempa Quanta Mengurai Seni. Yogyakarta: Badan Penerbit Institut Seni Indonesia. 